\title{
$\square$ Representing Childhood and Forced Migration: Narratives of Borders and Belonging in European Screen Content for Children
}

\author{
-Christine Singer, Jeanette Steemers, and Naomi Sakr
}

\begin{abstract}
This article explores representations of childhood and forced migration within a selection of European screen content for and about children. Based on the findings of a research project that examined the intersections of children's media, diversity, and forced migration in Europe (Euro-Arab Children's Media), funded by the UK's Arts and Humanities Research Council, the article highlights different ways in which ideas of borders and belonging are constructed and deconstructed in a selection of films and television programs that feature children with an immigration background. Drawing on ideas around the "politics of pity" (Boltanski; Chouliaraki), the analysis explores conditions under which narratives of otherness arise when it comes to representing forcibly displaced children within European-produced children's screen media. It also examines screen media that destabilize borders of "us" and "the other" by emphasizing the agency of children from migration backgrounds and revealing both the similarities and the differences between European children with immigration backgrounds and White European-born children. It is argued here that these representations destabilize narratives of borders and otherness, suggesting that children with a family history of immigration "belong" to European societies in the same ways as White European-born children.
\end{abstract}

Keywords: migration; children; Europe; film; television; media; broadcast; race; borders

The number of people displaced by war and conflict is currently the highest seen in Western and Central Europe since the Balkan crisis of the 1990s (H. Holland). As a result of the civil war in Syria that began in 2011, by January 2017, 577,300 Syrians had arrived in Germany, 116,400 in Sweden, 51,400 in the Netherlands, 31,000 in Denmark and 11,500 in Bulgaria (Eurostat). Among the displaced Arab populations in European countries there are large numbers of children 
(UNICEF). The lives of these children, caught up within forced migration, are entangled with a variety of borders, both in a literal and metaphorical sense. They have crossed physical borders on their journeys to Europe, involving checkpoints, fenced-in camps, and the sea (Akesson 81). Furthermore, upon arrival in Europe, children often find themselves isolated by symbolic boundaries, including racist stereotyping, language barriers, and limited economic opportunities (Spyrou and Christou 2).

Media narratives can play a key role in either tackling or reinforcing the boundaries and barriers faced by young people newly arrived in Europe. The exposure of children and youth to certain media representations has been linked to the endorsement of stereotypes around gender (Herrett-Skjellum and Allen 157), race (Mastro and Kopacz 317-20), and perceptions of body image (Dohnt and Tiggemann 934-35). For example, a longitudinal survey of over 300 children from diverse ethnic backgrounds in the United States suggested that children's frequent exposure to discriminatory depictions of Black characters on television resulted in a decrease in self-esteem among African-American children (Martins and Harrison 351-52). These and other studies, which show the impacts of negative representations (Martin; Villani), would suggest that balanced representations of children with immigration backgrounds could play an important part in helping them feel as though they are accepted by and are part of the host societies where they and their families have sought refuge. The European media, however, often construct displaced people as fundamentally different from White Europeans (Makarychev 747-49) and as victims of conflict and persecution (Wilson 2-3). For example, European news reports on people affected by the Syrian conflict often position refugees as powerless victims (Chouliaraki and Stolic 1164), often excluding information on the historical, cultural, and political circumstances of forcefully displaced people (Wright 464). A media focus on the suffering of refugees operates in the interests of humanitarian aid and advocacy (McLaughlin 1758); as this article demonstrates, however, such representations also reinforce ideas about metaphysical borders that separate White European children from recently displaced children, who are depicted as the "other" (McLaughlin 1758-60).

In turn, children's own perceptions frequently diverge from stereotypes that depict people with immigration backgrounds as victims or outsiders. As discussed later, both first-generation 
${ }^{1}$ The term "firstgeneration immigrant" refers to a person who was born in another country and has become a citizen and resident in a second country after relocation. The term "second-generation immigrant" refers to a person who was born in and is residing in the same country, but who has at least one "first-generation immigration" parent.

${ }^{2}$ See the Euro-Arab Children's Media website for details on the project's research aims and outputs. and second-generation immigrant children ${ }^{1}$ often feel as if they belong to both their family's country of origin and to the country where they are living (Abebe 70; Kebede 6; Kumsa 248). For example, Sewite Solomon Kebede conducted a study with Ethiopian children aged eight to twelve who were born in Ethiopia but had migrated to the US at a young age. She concluded that these children felt at home in their host country, the US, because they spoke English fluently and had developed friendships with children born in the US; they also, however, maintained a sense of belonging to Ethiopia based on their ethnic and linguistic identities. This example suggests that "belonging" is not necessarily defined by the ethnic or national origin of one's parents; instead, belonging is a subjective, personal experience, entangled with social environments and relationships (Kebede 22-23). Therefore, belonging is understood here as a human need and a longing to connect with people and communities similar to oneself "and thus to be-long" (Kebede 22).

These overlapping narratives of borders, belonging, childhood, and immigration are discussed here with reference to a selection of European children's films and television programs focused on clandestine migration and displaced children, as well as on Europeanborn children of immigrants living in Europe. The selection was compiled as part of an impact and engagement project, "Collaborative Development of Children's Screen Content in an Era of Forced Migration Flows: Facilitating Arab-European Dialogue" (2017-18) ${ }^{2}$ funded by the United Kingdom's Arts and Humanities Research Council (AHRC). The project identified thirty-six European films and television programs, which were commissioned, produced, and distributed predominantly by European public service broadcasters (PSBs), operating according to their public service mandate to educate and inform. The majority of European children's content that addresses forced migration and related subjects are thus made by White Europeans for predominantly White European audiences who have not experienced conflict and migration themselves. As discussed later, these borders between media producers, audiences, and subjects have, in some contexts, translated into totalizing ideas of children caught up within forced migration as alien "others."

The examples discussed here include PSB programs made in Belgium, Denmark, Germany, the Netherlands, Serbia, Slovenia, Switzerland, and the UK, as well as from Canada, the 
US, and Malaysia/Yemen. As part of the project, the programs were discussed by a total of ninety invited Arab and European media practitioners, representatives of children's advocacy organizations, and academics, at three international workshops: the Children's Global Media Summit in Manchester, UK, in December 2017; the CPH:DOX Documentary Film Festival in Copenhagen, Denmark, in March 2018; and at the Prix Jeunesse International Festival in Munich, Germany, in May 2018. These workshops provided opportunities to explore the different contexts of production and distribution and to document responses by participants, including producers of several of the thirty-six program examples collected, about their experiences of production.

Using the content that featured in the AHRC project, this article explores different ways in which narratives of borders and belonging are constructed or deconstructed in European children's screen media that show children with an immigration background. There is a distinction to be made between two types of children who are represented in the films and television programs; namely, those who have been forcibly displaced and those who have not. The latter are either immigrants by choice or the offspring of immigrant parents. This article focuses on the representations of childhood and migration within the selected examples, since aspects of production and distribution have been discussed within other outputs of the project (Steemers, Sakr, and Singer, "Facilitating"). Drawing on ideas around the "politics of pity" (Boltanski 3-9; Chouliaraki 187, 190) and its alternatives, such as the notions of living "togetherin-difference" (Ang 141), "narratability" (Chouliaraki and Stolic 1164, 1174), and "the struggle for belonging" (Kebede 5), this article compares and contrasts how these European-produced children's programs approach notions of borders and belonging.

This article first discusses factual content for European children that explores the phenomenon of recent refugee arrivals in Europe, but perhaps unwittingly reinforces borders between European-born children and newly arrived children by operating within a "politics of pity." Second, this article explores the strategies deployed by producers in European children's films and television programs that work to problematize the barriers that separate European children, by focusing on how recently displaced children, second-generation immigrant children, and children without migration backgrounds are living "together-in-difference." Third, 
this article explores screen content that constructs forcefully displaced children as resourceful and capable agents of their own destinies. The final section discusses representations of the "struggle for belonging" experienced by recently displaced children and by European-born children whose parents have immigrated to Europe.

\section{Borders of "Us" and "Them"}

The European mass media have frequently pursued a discourse that constructs children caught up in forced migration as fundamentally different from European-born children. Alongside the news media, Western humanitarian organizations have circulated representations of displaced children as "border subjects," epitomized, for example, by reports showing rubber dinghies, and children's toys and shoes discarded on European shores (McLaughlin 1760). These media narratives are often implicated in a "politics of pity" (Boltanski 3-9; Chouliaraki 187, 190) that seeks to invite an empathetic response from viewers in Europe. Building on the German philosopher Hanna Arendt, Luc Boltanski's description of the politics of pity is based on the following two observations: first, there is a border between those who suffer and those who do not, and, second, there is a focus on the "spectacle of suffering" (3), with unfortunate people being observed by those who do not share their suffering and "who do not experience it directly and who, as such, may be regarded as fortunate or lucky people" (3). This distance between media subjects and producers/audiences has often resulted in stereotyping when it comes to representing racially marginalized groups, who are often positioned as "the other," "exotic," or as inferior counterparts to White Europeans (Mano 4-6; Ramasubramanian 249; Sabry 182).

This politics of pity can be sensed in some European documentary films focused on children's encounters with (physical) borders. One example is Hello Salaam (Brand), made by Dutch filmmakers, which follows two ten-year-old White Dutch boys, Merlijn and Sil, who spend their school holidays with their volunteer mothers in a refugee camp on the island of Lesvos in Greece. Here, they befriend a group of boys who have recently fled their homes in Syria and Afghanistan. A key sequence in the film shows Merlijn and Sil contemplating a stretch of the Aegean Sea that separates Turkey from Greece, where thousands of refugees 
have made their way to Europe in overcrowded boats, and remarking that this part of the sea is "very dangerous" to cross. The following sequence shows long-distance, wide-angle shots of the two boys walking toward a vast pile of discarded life vests, shoes, and rubber dinghies, epitomizing the idea of "innocent childhoods destroyed" (McLaughlin 1760). The film contrasts these childhood experiences with those of Merlijn and Sil, who, in the opening sequence, board a plane together, calmly looking out of the window during takeoff. By contrasting the journeys of children born inside and outside of Europe, Hello Salaam positions recently displaced non-European children beyond European concepts of childhood as an unfettered, innocent, and protected period (P. Holland 8-12). ${ }^{3}$

These juxtapositions between Dutch and Arab childhoods in the film could be interpreted as depicting White European children as "the fortunate" and children from forced migration backgrounds as "the misfortunate." As noted earlier, a politics of pity can create a discourse of self and other by distinguishing between those who suffer and those who do not (Boltanski 3-9). The politics of pity could thus be seen to operate according to postcolonial theories of identity construction, which involve identifying an "Other" through alignments of race, gender, religion, and class (Bhabha 18-19; Hall, “Who Needs 'Identity'?" 19, 33; Hook 701703). For example, Stuart Hall has suggested that racist stereotyping relies on an ideological construction of otherness as "the product of the marking of difference and exclusion" "Who Needs 'Identity'?" 17), arguing that such an essentialized understanding of identity neglects the fluidity of "same" and "the other," as well as the possibility for commonalities and similarities between people of different backgrounds (17).

Despite evoking narratives of borders, Hello Salaam also emphasizes the friendships that unfold between the Dutch boys and the Syrian and Afghan boys. Scenes in which Merlijn and Sil drink tea with camp children, chat with them, and have a snowball fight suggest that displaced children and European children share some "ordinary" childhood experiences despite their different backgrounds. The film thus acknowledges the blurred and slippery borders between childhood experiences that are often perceived as different; yet its focus on evoking notions of equality through friendship is potentially compromised by the fact that the befriending is initiated by White European children. Merlijn and Sil are shown to reach out to 
displaced children-not vice versa-by travelling to the camp, handing out food, and relying on a Google translation app to communicate with them. The film thus constructs a potentially problematic narrative in that it is told for Dutch children from the Dutch boys' point of view.

Differences and borders are also explored in the short Danish documentary Ferie på Flygtningeøen (Vacation on Refugee Island; Schmedes). The film centers on Alvin, a ten-year-old White Danish boy who enjoys a holiday with his father (the film's director) on Samos, Greece, and who sets out to meet children who live in refugee camps on the island, intending to give them sweets. Alvin is shown to visit a fenced-in refugee camp that is portrayed as a place of tension and surveillance: in a scene toward the end of the film, a guard is shown interrupting Alvin's conversation with a group of camp children, after which the camera is abruptly switched off. We then learn from Alvin that he and his father were detained at the local police station for six hours, but that they were ultimately able to return to their hotel. The camp is thus represented as a "space in a permanent state of exception" (Zeveleva 41), where displaced children are victimized by the power of the nation-state. While European children emerge as "the fortunate," able to return to the safety of their homes, children who have had to flee their homes are situated in a state of limbo and denied belonging to any state-either the one they have left or a new one. Ferie på Flygtningeøen thus depicts children living in refugee camps as liminal subjects, positioned in-between bounded nations.

Within European media discourse, refugee children are often defined by a "position between, rather than within, sovereign states" and by a "lack of belonging" that cannot be resolved by merely crossing a political border (Haddad, qtd. in Wilson 41). Hello Salaam is a film that teases out this lack of belonging. A conversation between Merlijn and Sil reveals that many families who seek asylum in Europe are stranded in Lesvos because they cannot find the financial means to settle in Europe. In contrast, toward the end of the film, Merlijn and Sil state that they will be leaving the camp soon, as their school holidays are coming to an end. As with Ferie på Flygtningeøen, in Hello Salaam, the children who live in the camps are neither able to belong to Europe nor are they able to return and belong to their country of origin; their ability to belong is undermined and incomplete. 
Films that center on children's liminal positioning in relation to bounded nations often neglect these children's diverse lives prior to their flight, including their families, games, and daily routines. This tendency to decontextualize displaced children's lives is entangled with the concept of the "spectacle of suffering" (Boltanski 3), which involves considering "seeing" and "looking" as different concepts, because sufferer and observer are physically distant. News programs for children present further examples of representations of children caught up in forced migration from a distanced gaze. For example, an episode of CBBC Newsround (a UK news magazine program for children) entitled "Ayshah Meets Child Refugees in Greece" (CBBC) comprises interviews with refugee youths whose faces are hidden from the camera and whose personal stories are not further explored. The program's distance from its subjects can be said to create a "spectacle of suffering," where unfortunate youths are being observed by those, the viewers, who do not experience this kind of suffering themselves.

Certain ethical issues arise from these attempts to represent displaced children, because by revealing their faces, identities, and reactions without obtaining their explicit consent, the filmmakers run the risk of intruding on children's personal boundaries. For example, the director of Ferie på Flygtningeøen entered the refugee camp without having sought permission beforehand, and some Copenhagen workshop participants interpreted this scene as an infringement of children's rights to privacy and anonymity. Furthermore, workshop participants with experience working in the Arab region noted that people who live in refugee camps often do not want to be filmed because they feel ashamed of their situation and are wary of the intentions of Western journalists based on previous negative experiences.

While the content discussed so far explores the borders encountered by displaced children, the following section turns to producer strategies that aim to deconstruct symbolic boundaries and barriers between children with and without immigration backgrounds.

\section{Negotiating "Together-in-Difference"}

The AHRC project identified films and television programs for children that help to deconstruct narratives of "us" and "the others" by highlighting commonalities between White European children and children from immigration backgrounds living in Europe. These films 
and television programs address issues of borders, differences, and flight, but, instead of drawing from the binaries of "us" and "them" that inform the politics of pity, they engage with what Stuart Hall has called "the really hard game" ("Old and New Identities" 51)-the ways in which similarities and differences coexist and where people with different ethnic, linguistic, and religious backgrounds live side-by-side. len Ang argues that these complexities of contemporary societies can best be understood as "living together-in-difference" $(141,150)$ and are characterized by a "hybridity" of identities (141). As Ang suggests, hybridity stands as an important corrective to concepts such as "multiculturalism" and "diaspora," which have tended to construct the identities of diasporic groups as "closed off" and separated from the host community (141). The term "hybridity" is ambivalent, however, suggesting the possibility of distilling the essence of identities, rather than acknowledging constant changes in identities as a consequence of transnational flows of people, media, capital, and ideas (Kraidy 321-24; Spivak 191; Yue 776). Despite these shortcomings, "hybridity" provides a useful starting point for highlighting the porous nature of borders between people with and without migration backgrounds, which allows an emphasis on the multiple expressions of living with differences and similarities (Yue 780).

Certain examples of European public service content for children embrace the idea of living "together-in-difference" by representing European cities as spaces where children with different ethnic, linguistic, and religious backgrounds can form friendships. The German reality documentary series Berlin und Wir (Berlin and Us; Raab) is an example of factual content that destabilizes borders of "us" and "them" by exploring interactions among children with diverse backgrounds. Commissioned by the German PSB, Zweites Deutsches Fernsehen (ZDF), the aim of the series was to follow a group of German-born children and children who came to Germany as refugees, in order to explore whether they can live together and become friends. The series unfolds in Berlin, a city space that is shared by children with forced migration backgrounds and German-born children. Each episode openly addresses differences between the children, for example around religious practices, but they also attempt to break down barriers by showing children engaged in shared activities, such as baking, playing football, and rowing. The program's commissioning editor recalled that, during the filming process, 
the group of teenagers grew together as a team, developing friendships and tolerance for each other (Steemers, Sakr, and Singer, "London" 8). In concentrating on friendships and similarities despite differences, the program refrains from representations of recently displaced children as "the unfortunate" and White European children as "the fortunate," suggesting that forcefully displaced children "belong" in Berlin in the same way as German children without an immigration background.

Other examples that address belonging and living "together-in-difference" focus on the lived experiences of European-born children whose parents immigrated to Europe. For example, the Dutch short documentary Heijplaters (Harbourboyz; Marks) introduces five boys whose parents are Turkish, Syrian, Chinese, Suriname, and Dutch and who all live in the harbour district of Rotterdam. Heijplaters depicts these boys as fully integrated into Dutch society, since they are shown go to the same school, live in the same neighborhood, and speak Dutch without any accent. Although their parents came from elsewhere, the film does not make immigration a main focus of the narrative; instead, the harbour of Rotterdam is represented as a microcosm of Dutch society where children of different ethnic and cultural backgrounds establish friendships and share daily activities, including swimming, listening to music, and playing football. Mirjam Marks, the film's director, explained that she deliberately sought to make a film that focuses on friendships and similarities between children from different cultural backgrounds-rather than the differences between them-in order to address what she sees as increasing polarization between people of different ethnicities in the Netherlands. In underlining the diversity of a Dutch city, the film challenges the imagined borders between White European children and children with family histories of immigration by redefining such boundaries as porous and unstable. Second-generation immigrant children, while often coded as "different," are depicted by the film as "rooted" within European society.

A similar focus on living "together-in-difference" can be found in the UK live action preschool drama series Apple Tree House (Vanderpuye, Timotheou, and Akinsiku). This program centers on a group of friends, including children who are second-generation immigrants, and their families, who all live on an inner-city social housing estate. Scriptwriting choices were central to the series' attempts at deconstructing perceived borders and barriers 
between children with and without immigration backgrounds. The narratives of Apple Tree House address racial and religious differences, which are woven into the stories through subplots, rather than forming the main plot. One example of this strategy is an episode in which a Black British girl, Sam, and her parents organize a dinner party for their friends on the estate. As it is Ramadan, and her Muslim friend Mali's family is fasting, they decide to have the dinner later than planned. Sam still struggles, however, to accommodate everyone's dietary requirements, as Mali does not eat pork, and Bella-a White girl-has a nut allergy. Ultimately, Sam comes up with the plan to have a potluck dinner to which everyone brings their favourite dish. By showing children with diverse backgrounds sharing activities and solving problems, the program deconstructs borders and barriers between White British children and British children with a family history of immigration. This approach was described by one workshop participant as "showing the diversity but not naming it" (Steemers, Sakr, and Singer, "Manchester" 11), meaning that differences in children's racial, cultural and religious identities are addressed in the narrative, but not as a central storyline. Instead, the script underscores the children's mutual sense of belonging to their community, which stands for UK contemporary society.

Apple Tree House's highlighting of belonging emerged from an ethnically and religiously diverse cast of children and adults, which, according to the producer, allowed the team to deliberately "subvert the stereotypes in terms of who can do what" as storylines developed (Steemers, Sakr, and Singer, "Manchester" 7). Just as important for emphasizing belonging over exclusion was the use of an ethnically diverse team of scriptwriters, who based the stories on their own experiences of growing up in inner-city communities. This approach to writing is relatively rare in the UK, where producers, directors, writers, and actors from ethnic minorities are underrepresented within the country's television workforce (Ofcom). The goal, according to producer Gregory Boardman, was to create an engaging drama that British children of all backgrounds can relate to, rather than to emphasize racial or religious differences (Steemers, Sakr, and Singer, "Manchester" 11).

Diverse soundscapes can also help to break down barriers and construct narratives of belonging. A program that weaves linguistic diversity into its soundscape is the German 
preschool animation series JoNaLu (Mey, Schulden, and Werner), which airs on the country's public service children's channel, KiKa. JoNaLu addresses immigration and language barriers by featuring characters that speak foreign languages and have different accents. In one episode, a Turkish-speaking butterfly, Sibel, speaks Turkish and plays "shop" with two German-speaking mice. With two languages heard in the episode, the producers wanted to reflect children's experiences at nursery and in kindergarten, where preschool children might hear different languages spoken. One of the producers said that children with migration backgrounds were pleased to see television characters speaking their native languages in JoNaLu, while German-born children could identify with the characters even without understanding every word of the dialogue (Steemers, Sakr, and Singer, "Facilitating" 10).

\section{Narratability and Agency}

Another way of breaking down barriers between children of different heritage is by depicting children as resourceful agents. Films and TV programs which do so operate through the concept of "narratability" (Chouliaraki and Stolic 1164, 1174); that is, they involve representations where disadvantaged people are able to voice their own experiences, aspirations and concerns and are represented as agents. Lilie Chouliaraki and Tijana Stolic suggest that the politics of pity appeals to Europeans because it emphasizes their "formal responsibility" $(1163-64,1173)$ to care for displaced families, but that this approach actually reinforces borders between Europeans as "us" and refugees as "them" by denying refugees the opportunity to voice their own concerns (1173). By contrast, narratives focused on personal stories and the agency of displaced people emphasize shared human capacities and so blur the boundaries around "who speaks." Representations operating through narratability can thus allow viewers to experience-rather than merely intellectualize-their own responsibility toward people affected by forced migration (Chouliaraki and Stolic 1174).

European children's films and television programs that focus on narratability foreground the skills and individuality of children with and without forced migration backgrounds and so deconstruct differences and barriers between them. Although this type of content often addresses children's experiences of flight, it also places these children's problem-solving 
skills and courage at the heart of the stories. These narratives may be presented through displaced children's own voice-overs and/or point-of-view and focus on how they overcome challenges through their own agency, with adults playing a more peripheral role. For example, in Nur (Tokuhisa), a Slovenian drama for six-to-nine-year-olds, made as part of a European Broadcasting Union (EBU) collaboration, a young Syrian girl who has been sent to live with her uncle in Slovenia is confronted with the problem of having to replace her uncle's rose water, which she has spilled by accident. In the process of searching for rose petals, she makes the acquaintance of a Slovenian girl, called Pia, who helps her to find a rosebush. Nur subsequently shows Pia how to make the rose water. In Swing (Vucic), a Serbian drama made for the same EBU exchange, two Syrian brothers on their way to Germany are shown hiding from police on a Serbian farm with the assistance of a Serbian boy. These films depict both White European children and Syrian children as independent individuals who master challenges and solve problems together.

A documentary film that focuses on the determination of a displaced child that speaks for herself is the Danish documentary Laylas Melodi (Layla's Melody; Pedersen and Bakhtari), which, in this case, looks at the experience of an internally displaced girl in Afghanistan. Laylas Melodi follows eleven-year-old Layla, who lives in a Kabul orphanage. Her father was killed in the war and she has not seen her mother for four years. Layla feels happy in the orphanage, however, because she can go to school and play music. Layla learns that her mother is coming to visit her and is torn between excitement about the reunion and fear that she might be expected to return to her mother's village, where she would come under pressure to get married. The film was interpreted by participants in the Copenhagen workshop as a positive representation of a displaced girl with agency, and as one that allows viewers to connect with the main character on an emotional and personal level rather than through encouraging pity. According to a representative from the Danish Film Institute, children engaged with Laylas Melodi because children are "defining themselves as children and not as victims" (Steemers, Sakr, and Singer, "Copenhagen" 23).

The Dutch documentary film Het Haar van Ahmad (Ahmad's Hair; Koenen) embraces narratability by following Ahmad, a Syrian boy recently arrived in the Netherlands, who grows 
his hair in order to donate it to a charity that makes wigs for Dutch children who have lost their hair to cancer. In a conversation with his Moroccan friends, Ahmad explains that, by donating his hair, he wants to "give back" to Dutch society and is thus shown taking on social responsibility and trying to engage with the community of his host country. Ahmad's ability and his intention of helping sick European children reverses the politics of pity, and its depictions of displaced children as the "unfortunate" and White European-born children as "the fortunate."

More optimistic representations focused on the agency of recently displaced children could be critiqued for attributing a sovereignty and optimism that conceals the reality of these children's lives. For example, Chouliaraki and Stolic argue that showing children to be in control of their destinies runs the risk of ignoring historical circumstances that are beyond the control of displaced individuals, including civil war, violence, and poverty (1164-65). Others, however, suggest that visual storytelling featuring disadvantaged children who succeed and are mastering problems can promote resilience, self-confidence, and hope in children who watch the stories (Götz; Holler). For example, a 2018 study by the International Central Institute for Youth and Educational Television (IZI) suggested that, rather than seeing repeated descriptions of the problems of refugees, children and adolescents born in Germany want to see how difficulties and differences can be overcome or what opportunities there are for living together with people recently arrived in Germany (Holler 46).

\section{A Struggle for Belonging}

As noted earlier, representations operating through the politics of pity often deny recently displaced children a space within European host societies (Kebede; Spyrou and Christos 2; Wilson 10). Yet sociological studies suggest that young children who spent their early childhood years in one country and experience their adolescent years in another do not necessarily feel excluded from the society of their host country. Instead, children who have migrated to another country often feel as though they belong to both their country of origin and their host society (Abebe 70; Kebede 6; Kumsa 248); but this simultaneous sense of belonging to different communities can create tensions around values, religion, and cultural beliefs. 
Some of the content discussed here engages with this "struggle for belonging" (Kebede 5-6) experienced by forcefully displaced children. Berlin und Wir, mentioned above, suggests that Arab children with forced migration backgrounds experience a sense of belonging to both Germany and their countries of origin. In one episode, an eleven-year-old Syrian-born girl, Rashad, explains that she came to Germany as a refugee speaking only Arabic and some English. Two years later, she is fluent in German and sometimes struggles to find the right words in Arabic, suggesting that knowledge of German roots her more within German society. The same episode shows interactions between Malina, a White German-born girl, and Rashad during a football training session. Malina asks Rashad if she intends to wear the hijab (headscarf) when she is older, to which Rashad responds that this is part of her religious tradition. Malina then remarks that she sees the headscarf as a symbol of female oppression. This sequencing of events could be interpreted as enforcing, rather than destabilizing, borders between Syrian and White German children by depicting Rashad's faith as the "essence" of her identity while allowing Malina to judge her religious beliefs. On the other hand, as a producer of the program explained in the Munich workshop, the show is not scripted and the conversation about the hijab emerged spontaneously among the teenagers. Hence, the program highlights the symbolic borders-including religious differences-encountered by Muslim children living in Germany, but also these children's sense of belonging to both Germany and their country of origin (Steemers, Sakr, and Singer, "Facilitating" 65). The emphasis Berlin und Wir places on the multidimensional experiences of belonging destabilizes concepts that construct forcibly displaced children as fundamentally different to White European-born children. In this way, the program underscores Hall's concept of identities, which suggests that seemingly rigid boundaries between "us" and "the other" are, in fact, fluid and difficult to disentangle ("Old and New Identities" 48).

This sense of belonging to both societies is also tackled in the German drama series Dschermeni (Choroba, Teichmann, Döring, and Steinhöfel) aimed at nine-to-twelve-year-olds, which addresses belonging and the nature of invisible borders through the lens of racism, discrimination, and the limited social opportunities that can compromise belonging for firstand second-generation immigrant children. The drama follows four protagonists from different 
demographic and ethnic backgrounds who live in a German city and often spend time together in a hut by a lake, where they play games and share their problems. The series' focus on children's activities reveals the struggle for belonging experienced by second-generation immigration children in Germany, embodied by Rüyet, a character whose parents and grandparents are Turkish. Rüyet is shown rejecting her Turkish grandfather's views on gender roles, which prescribe a passive role for women within society and the family. These different views are shown to create tensions within Rüyet's family, illustrated by an episode in which her grandfather tells her that she is "not really Turkish" because she wears jeans and does not know how to cook. In another episode, Rüyet discovers that her older brother, Boran, is gay, which triggers a conflict within the family. As a result of the family's rejection of Boran's sexual orientation, Rüyet and Boran even decide to leave their home toward the end of the series. Dschermeni thus suggests that while second-generation immigration children belong to both German society and the social practices of their country of origin, other multiple dimensions of belonging, including sexuality, can create further tensions and conflict. Key to the program's engagement with children's struggle for belonging was the scriptwriters' attempt to create a series that approached questions of immigration through the eyes of children themselves. Klaus Döring, both a producer and writer of Dschermeni, explained that throughout the show, there is "no scene where there is no kid," reinforcing the perspectives and experiences of children from a variety of ethnic and cultural backgrounds, to the effect that "all the time we just know what the kids know" (Steemers, Sakr, and Singer, "Munich" 14). Yet the drama's focus on Rüyet's rebellion against her family's views on gender and sexuality could also be interpreted as evoking a Eurocentric narrative that constructs German values as more desirable, and thus "superior," in relation to those prevalent among Turkish communities.

By focusing on the perspectives and shared activities of children from diverse backgrounds, Dschermeni emphasizes "living together-in-difference." It also, however, addresses the borders that arise from lengthy asylum processes in Germany, illicit working by refugees, the deportation of those who are deemed economic migrants, and encounters with racism. For example, in the first episode a young Syrian refugee, Yassir, is bullied by two German boys until Rüyet intervenes. As the narrative unfolds, another protagonist, Aminata, faces deportation 
to Senegal because her family are not deemed asylum-seekers or refugees, in the process showing that refugee status is always contested and that belonging is constantly negotiated. One Syrian-born participant living in Berlin remarked during the Munich workshop that the series' explanation of asylum procedures from children's perspectives functioned almost as a form of "political education" for children in Germany (Steemers, Sakr, and Singer, "Munich" 9).

The Dutch documentary film De Kinderburgemeester (The Children's Mayor; Koenen) provides a final example that alludes to the struggle for belonging and children's encounters with barriers and borders that are underpinned by racial and social discrimination. The film unfolds from the perspective of Yassine, a Moroccan-Dutch boy who becomes the first children's mayor in Gouda, the Netherlands. Yassine has two aims in office, namely, to encourage children with and without immigration backgrounds to interact with each other more and to meet his role model, the Moroccan-born mayor of Rotterdam, Ahmed Aboutaleb. Susan Koenen, the director, explained that it was her aim to make a film that would present a role model for Dutch children with Moroccan backgrounds, since she felt that there are not many positive role models for them in society. The film's observations of the barriers encountered by children who are second-generation immigrants are crystalized in a scene where Aboutaleb tells Yassine that he will have to work "extra hard" to succeed in life, as Dutch people often hold prejudices against people of Moroccan origin. The filmmaker said that she had "really wanted to wake up Dutch children without Moroccan background [sic] to know this. They don't know how it feels" (Steemers, Sakr, and Singer, "Copenhagen" 22). In placing a child from an immigration background as a role model and leader, De Kinderburgemeester challenges stereotypes of children with immigration backgrounds as outsiders in European societies, revealing these children as resourceful, politically engaged individuals who belong in Europe as citizens. A Danish producer who was not born in Denmark commended this approach because it raised aspirations in children with immigration backgrounds. He commented:

I really like the film. It shows that, even though you have another skin color, you can still have dreams and be able to pursue them. When I was growing up, I was limited. If I said I 
wanted to do something [I was told] "why don't you do something else?" I really like the perspective that he might have a dream of being there one day and he's trying to pursue it. (Steemers, Sakr, and Singer, "Copenhagen" 22)

Therefore, De Kinderburgemeester works to challenge problematic ideas that define secondgeneration immigrant children in relation to borders and differences, constructing these children instead as "bridges" between European children of different ethnic, religious, and linguistic origins. The film thus suggests that the actions, knowledge, and experiences of European children with a family history of immigration are key to building more inclusive and non-racist societies in the future.

\section{Conclusion}

This article has explored ways in which narratives of borders and belonging emerge within European screen content for children that deals with forced migration, immigration, and diversity. It has suggested that some examples of factual content operate according to a "politics of pity" that, in turn, constructs a border between European-born children and children who have arrived in Europe through forced migration. That some of this content was commissioned to fulfill a public service mandate suggests that even media made with the aim of educating children in the audience, to serve a public good, can slip into paternalistic narratives when it comes to representing children with immigration backgrounds.

Other examples explored here, however, reveal ways in which industry professionals work toward destabilizing and deconstructing boundaries and barriers between children of diverse backgrounds, for example, by emphasizing the principles of "together-in-difference" (Berlin und Wir, Heijplaters, Apple Tree House) and "narratability" (Swing, Nur, Laylas Melodi, Het Haar van Ahmad). These films and television programs represent children from different linguistic, ethnic, and religious backgrounds as individuals in their own right, who, despite certain differences, have many things in common. Examples like these emphasize the agency and resourcefulness of displaced children. Finally, content that explores the ways in which first- and second-generation immigration children obtain a sense of belonging to both their country 
of birth and their parents' country of origin (Berlin und Wir; Dschermeni; De Kinderburgemeester) destabilizes invisible borders and barriers, such as racial and religious discrimination. Highlighting these manifold experiences of borders and belonging can redefine perceived distinctions between children with and without histories of immigration as porous and shifting. Working toward these balanced representations at a time when populist parties are increasingly gaining power across Europe could provide a crucial counterweight to discriminatory ideas that separate White European children, who emerge as "us," from European children who are first- and second-generation immigrants, who are depicted as "the other."

In turn, the examples of screen content discussed here could open up opportunities for European children to think differently about what it means to belong by identifying with the stories and experiences of displaced children. Except for very few studies (Götz; Holler), however, what is missing is a sense of the extent to which children with migration backgrounds and their families engage with this sort of content. It is difficult to obtain audience data on disadvantaged social groups, and even more so with recently displaced children. The next steps would be to go beyond research about content or research with producers to explore how children with forced migration and immigration backgrounds select and engage with content that features diverse casts and stories that reflect their experiences.

\section{Acknowledgement}

The UK's Arts and Humanities Research Council (Grant No. AH/R001421/1) supported the research in this article. 


\section{Works Cited}

Abebe, Alpha. "I Turn Not towards My Mother's Land but into My Own': Exploring Young Ethiopian Diasporic Spaces." M.A. Thesis. York U, 2009.

Akesson, Bree. "Arrested in Place: Palestinian Children and Families at the Border." Children and Borders, edited by Spyros Spyrou and Miranda Christou, Palgrave, 2014, pp. 81-98.

Ang, len. "Together in Difference: Beyond Diaspora, into Hybridity." Asian Studies Review, vol. 27, no. 2, 2003, pp. 141-54, doi: 10.1111/14678403.00147.

Arendt, Hannah. On Revolution. Penguin Classics, 2009.

Bhabha, Homi K. "The Other Question..." Screen, vol. 24, no. 6, 1983, pp. 18-36, doi: 10.1093/screen/24.6.18.

Boltanski, Luc. Distant Suffering: Morality, Media and Politics. Cambridge UP, 1999.

Brand, Kim, director. Hello Salaam. Produced by Hasse van Nunen and Renko Douze for Een van de Jongens, broadcast by NPO Zapp, 2017.

CBBC. "Ayshah Meets Child Refugees in Greece." CBBC Newsround, 14 Mar. 2017, bbc.co.uk/newsround/39256235.

Choroba, Martin, Johanna Teichmann (Tellux Films), Klaus Döring, and Andrea Steinhöfel (Sad Origami), producers. Dschermeni. Broadcast by ZDF/KiKa, 2017-present.

Chouliaraki, Lilie. "Watching 11 September: The Politics of Pity." Discourse and Society, vol. 15, no. 2-3, 2004, pp. 185-98, doi: 10.1177/0957926504041016.

Chouliaraki, Lilie, and Tijana Stolic. "Rethinking Media Responsibility in the Refugee 'Crisis': A Visual Typology of European News." Media, Culture and Society, vol. 39, no. 8, 2017, pp. 1162-77, doi: 10.1177/0163443717726163.

Dohnt, Hayley, and Marika Tiggemann. “The Contribution of Peer and Media Influences to the Development of Body Satisfaction and Self-
Esteem in Young Girls: A Prospective Study." Developmental Psychology, vol. 42, no. 5, 2006, pp. 929-36, doi: 10.1037/0012-1649.42.5.929.

Euro-Arab Children's Media. "Children's Screen Content in an Era of Forced Migration: Facilitating Arab-European Dialogue." euroarabchildrensmedia.org. Accessed 12 Nov. 2019.

Eurostat. "Main Countries of Citizenship and Birth of the Foreign Born-Born Population." Eurostat: Statistics Explained, 1 Jan. 2017, ec.europa.eu/eurostat/statistics-explained/index. php?title=File:Main_countries_of_citizenship_and_birth_of_the_foreign_ foreign-born_population,_1_January_2017_(in_absolute_numbers_ and_as_a_percentage_of_the_total_foreign_foreign-born_population). png\#file. Accessed 12 Nov. 2019.

Götz, Maya. “Black, White, or Turkish? Do Children and Young People Want TV Characters with the Same Ethno-National-Cultural Background?" Televizion, vol. 23, 2010, pp. 16-19, yumpu.com/en/ document/read/6644382/black-white-or-turkish-1.

Hall, Stuart. "Old and New Identities, Old and New Ethnicities." Culture, Globalization and the World-System, edited by Anthony D. King, Macmillan, 1991, pp. 41-68.

-. "Who Needs 'Identity'?" Identity: A Reader, edited by Paul du Gay, Jessica Evans, and Peter Redman, Sage Publications, 2000, pp. 15-30.

Herrett-Skjellum, Jennifer, and Mike Allen. "Television Programming and Sex Stereotyping: A Meta-Analysis." Annals of the International Communication Association, vol. 19, no. 1, 1996, pp. 157-86, doi: 10.1080/23808985.1996.11678930.

Holland, Hereward. "Life Begins as One in a Million." UNHCR Canada, 8 Jan. 2016, unhcr.ca/news/life-begins-as-one-in-a-million/. Accessed 12 Nov. 2019.

Holland, Patricia. Picturing Childhood: The Myth of the Child in Popular Imagery. Tauris, 2004. 
Holler, Andrea. "Refugees on TV: What Children and Adolescents Would Like to See." Televizion, vol. 30, 2017, pp. 43-46.

Hook, Derek. "The Racial Stereotype, Colonial Discourse, Fetishism, and Racism." The Psychoanalytic Review, vol. 92, no. 5, 2005, pp. 701-34, doi: 10.1521/prev.2005.92.5.701.

Kebede, Sewite Solomon. "The Struggle for Belonging: Forming and Reforming Identities among 1.5-Generation Asylum Seekers and Refugees." Refugee Studies Center, Working Paper Series, no. 70, 2010, refworld.org/docid/55c9ff8a4.html.

Koenen, Susan, director. De Kinderburgemeester [The Children's Mayor]. Produced by Albert Klein Haneveld for Hollandse Helden, broadcast by NPO Zapp: KRO-NCRV, 2017.

-. Het Haar van Ahmad [Ahmad's Hair]. Produced by Albert Klein Haneveld for Hollandse Helden, broadcast by NPO Zapp: KRONCRV, 2016.

Kraidy, Marwan M. "Hybridity in Cultural Globalization." Communication Theory, vol. 12, no. 3, 2002, pp. 316-39, doi: 10.1111/j.14682885.2002.tb00272.x.

Kumsa, Martha Kuwee. "'No! I'm Not a Refugee!' The Poetics of Be-Longing among Young Oromos in Toronto." Journal of Refugee Studies, vol. 19, no. 2, 2006, pp. 230-55, doi: 10.1093/jrs/fel001.

Makarychev, Andrey. "Bordering and Identity-Making in Europe After the 2015 Refugee Crisis." Geopolitics, vol. 23, no. 4, 2018, pp. 747-53, doi: 10.1080/14650045.2018.1499380.

Mano, Winston. "Racism, Ethnicity and the Media in Africa." Racism, Ethnicity and the Media in Africa: Mediating Conflict in the Twenty-First Century, edited by Winston Mano, Tauris, 2015, pp. 1-27.

Marks, Mirjam, director. Heijplaters [Harbourboyz]. Produced by Nienke Korthof for Tangerine Trees, broadcast by NPO Zapp, 2018.

Martin, Ardis C. "Television Media as a Potential Negative Factor in the Racial Identity Development of African American Youth." Academic Psychiatry, vol. 32, no. 4, 2008, pp. 338-42, doi: 10.1176/appi. ap.32.4.338.
Martins, Nicole, and Kristen Harrison. "Racial and Gender Differences in the Relationship Between Children's Television Use and Self-Esteem: A Longitudinal Panel Study." Communication Research, vol. 39, no. 3, 2012, pp. 338-57, doi: 10.1177/0093650211401376.

Mastro, Dana E., and Maria A. Kopacz. "Media Representations of Race, Prototypicality, and Policy Reasoning: An Application of Self-Categorization Theory." Journal of Broadcasting and Electronic Media, vol. 50, no. 2, 2006, pp. 305-22, doi: 10.1207/ s15506878jobem5002_8.

McLaughlin, Carly. "They Don't Look like Children': Child AsylumSeekers, the Dubs Amendment and the Politics of Childhood." Journal of Ethnic and Migration Studies, vol. 44, no. 11, 2018, pp. 1757-73, doi: 10.1080/1369183X.2017.1417027.

Mey, Helge, Michael Schulden, and Ina Werner, writers. JoNaLu. Produced by Jan Bonath for Scopas Medien AG, broadcast by ZDF/ KiKa, 2008-2014.

Ofcom. "Diversity and Equal Opportunities in Television." Ofcom, 27 Sep. 2018, ofcom.org.uk/tv-radio-and-on-demand/information-forindustry/guidance/diversity/diversity-equal-opportunities-television. Accessed 12 Nov. 2019.

Pedersen, Jens, and Tai M. Bakhtari, directors. Tro Håb Afghanistan: Laylas Melodi [Faith-Hope-Afghanistan: Layla's Melody]. Produced by Jakob Gottschau for Pederson and Co., broadcast by DR, 2013.

Raab, Heike, director. Berlin und Wir [Berlin and Us]. Produced by Till Dreier, Christine Pfennig, and Markus Steiner for IMAGO TV, editorial by Margrit Lenssen and Eva Radlicki, broadcast by ZDF/KiKa, 2016 (season 1).

Ramasubramanian, Srividya. "Media-based Strategies to Reduce Racial Stereotypes Activated by News Stories." Journalism and Mass Communication Quarterly, vol. 84, no. 2, 2007, pp. 249-64, doi: 10.1177/107769900708400204.

Sabry, Tarik. Cultural Encounters in the Arab World: On Media, the Modern and the Everyday. Tauris, 2010. 
Schmedes, Frej, writer and director. Ferie på Flygtningeøen [Vacation on Refugee Island]. Produced by Dorthe Rosenørn Schmedes, broadcast by DR Ultra, 2017.

Spivak, Gayatri Chakravorty. A Critique of the Postcolonial Reason: Toward a History of the Vanishing Present. Harvard UP, 1999.

Spyrou, Spyros, and Miranda Christou. "Introduction." Children and Borders, edited by Spyros Spyrou and Miranda Christou, Palgrave, 2014, pp. 1-23.

Steemers, Jeanette, Naomi Sakr, and Christine Singer. "Copenhagen Workshop Briefing: Documentaries, Distribution, Ethics - Children's Screen Content in an Era of Forced Migration: Facilitating Arab European Dialogue, CPH:DOX Festival, Copenhagen, 19-20 March 2018." King's College London, 2018, kclpure.kcl.ac.uk/portal/ files/96194739/CopenhagenBriefing19to20March2018.pdf. Accessed 12 Nov. 2019.

-. "Facilitating Arab-European Dialogue: Consolidated Report on an AHRC Project for Impact and Engagement: Children's Screen Content in an Era of Forced Migration - 8 October 2017 to 3 November 2018." King's College London, 2018, kclpure.kcl.ac.uk/portal/ files/102210294/Consolidated_Report_FinalSV_221018.pdf.

-. "London Symposium Briefing: Invisible Children: Children's Media, Diversity and Forced Migration (14 September 2018)." King's College London, 2018, kclpure.kcl.ac.uk/portal/files/102211493/Symposium_ briefing_140918.pdf.

-. "Manchester Workshop Briefing - Children's Screen Content in an Era of Forced Migration: Facilitating Arab-European Dialogue, Children's Global Media Summit, BBC Media City, Salford Quays, 4 December 2017." King's College London, 2018, kclpure.kcl.ac.uk/portal/ files/88429031/ManchesterWorkshopBrie04122017.pdf.

-. "Munich Workshop Briefing: Drama, Storytelling, Empathy Children's Screen Content in an Era of Forced Migration: Facilitating Arab-European Dialogue, Prix Jeunesse International, Munich, 24 May 2018." King's College London, 2018, kclpure.kcl.ac.uk/portal/
files/100376382/Munich_briefing_draft_240518.pdf.

Tokuhisa, Kaya, director. Nur. Produced by Metka Dedakovic, executively produced for European Broadcasting Union (EBU) by Beryl Richards, distributed by EBU Exchange, 2014.

UNICEF. Latest Statistics and Graphics on Refugee and Migrant Children. 2017, unicef.org/eca/emergencies/latest-statistics-and-graphicsrefugee-and-migrant-children. Accessed 12 Nov. 2019.

Vanderpuye, William, Maria Timotheou, and Akindele Akinsiku, writers. Apple Tree House. Produced by Gregory Boardman and Eugenio Perez for Three Stones Media/Five Apples Ltd, broadcast by CBeebies, 2017-present.

Villani, Susan. "Impact of Media on Children and Adolescents: A 10-Year Review of the Research." Journal of the American Academy of Child and Adolescent Psychiatry, vol. 40, no. 4, 2001, pp. 392-401, doi: 10.1097/00004583-200104000-00007.

Vucic, Branko. director. Swing. Executively produced for European Broadcasting Union (EBU) by Beryl Richards, distributed by EBU Exchange, 2017.

Wilson, Rachel C. "Constructed Borders and Conditional Belonging: Refugee Narratives in Literature and Law." Macalester College, English Honors Projects, 41, 2017, digitalcommons.macalester.edu/english_ honors/41.

Wright, Terence. "The Media and Representations of Refugees and Other Forced Migrants." The Oxford Handbook of Refugee and Forced Migration Studies, edited by Elena Fiddian-Qasmiyeh, Gil Loescher, Katy Long, and Nando Sigona, 2014, pp. 460-72.

Yue, Ming-Bao. "Beyond Ethnicity, Into Equality: Re-Thinking Hybridity and Transnationalism in a Local Play from Hawai'i." Cultural Studies, vol. 23, no. 5-6, 2009, pp. 775-94, doi: 10.1080/09502380903132363.

Zeveleva, Olga. "Biopolitics, Borders, and Refugee Camps: Exercising Sovereign Power over Nonmembers of the State." Nationalities Papers, vol. 45, no. 1, 2017, pp. 41-60, doi: 10.1080/00905992.2016.1238885. 
Christine Singer is a Research Affiliate in the Department of Culture, Media, and Creative Industries $(\mathrm{CMCl})$ at King's College London. Her research centres on the intersections of childhood, screen media, race, and gender. She holds a Ph.D. from SOAS University of London, with her thesis, Transnational Narratives: Youth and Screen Media in Contemporary South Africa (2017), exploring childhood and youth in relation to film and television in post-apartheid South Africa.

Jeanette Steemers is Professor of Culture, Media, and Creative Industries at King's College London. She has published widely on European media industries and policy, including numerous articles and a book on preschool television. She is co-author of Screen Media for Arab and European Children (2019, with Naomi Sakr).

Naomi Sakr is Professor of Media Policy at the Communication and Media Research Institute (CAMRI), University of Westminster. She is the author of three books about Arab media, editor of two others, and co-editor of two, including Children's TV and Digital Media in the Arab World (2017, with Jeanette Steemers). 